\title{
Evaluation of Drug Use at Pasar Merah Public Health Center in Medan
}

\author{
Ismedsyah ${ }^{1}$, Takarina ${ }^{2}$ \\ ${ }^{1}$ Department of Pharmacy, Poltekkes Kemenkes Medan, Indonesia \\ ${ }^{2}$ Tanah Merah Public Health Center, Medan, Indonesia \\ Email: ismedsyah@gmail.com
}

\begin{abstract}
Abstrak-Pelayanan farmasi klinis di puskesmas diantaranya tentang evaluasi penggunaan obat. Penggunaan obat yang akan dievaluasi harus mengacu kepada indikator penggunaan obat. Tujuan dari penelitian adalah untuk mengetahui rata - rata obat tiap resep, persentase obat generik yang diresepkan, persentase antibiotik yang diresepkan, persentase injeksi yang diresepkan, dan persentase obat yang diresepkan dari DOEN di Puskesmas Pasar Merah Medan. Metode penelitian yang digunakan adalah deskriptifretrospektif dengan pengumpulan data pada dokumen yang ada serta wawancara terhadap kepala Puskesmas Pasar Merah Medan dan pengelola obat. Dari hasil penelitian, diperoleh bahwa rata - rata obat tiap resep masih tinggi, tidak sesuai standar yang ditentukan, persentase obat generik yang diresepkan kecenderungan masih tidak baik, persentase antibiotik yang diresepkan masih tergolong cukup tinggi, persentase injeksi yang diresepkan belum memenuhi indikator persentase peresepan injeksi, dan persentase obat yang diresepkan dari DOEN di Puskesmas Pasar Merah Medan tergolong cukup baik. Kesimpulan penelitian bahwa penggunaan obat di Puskesmas Pasar Merah Medan belum memenuhi indikator penggunaan obat.
\end{abstract}

Kata Kunci: Evaluasi; Penggunaan; Obat; Puskesmas

Abstract-Evaluation of drug use is one of the clinical pharmacy services at Public Health Center. Evaluation of the drugs use must refer to the indicators of drug use. This study aimed to determine the average number of drugs in each prescription, the percentage of prescribed generic drugs, the percentage of prescribed antibiotics, the percentage of injection, and the percentage of drugs prescribed from the DOEN (List of National Essential Medicines) at Pasar Merah Public Health Center Medan. This research was a retrospective descriptive study carried out by collecting data from the available documents as well as interviews with the head of Medan Pasar Merah Public Health Center and drug management officers.Through the research, it was found that the average number of drugs in each prescription was still high, not in accordance with the prescribed standards, the percentage of generic drugs prescribed was not good, the percentage of prescribed antibiotics was quite high, the percentage of injections prescribed did not meet the percentage indicator of injection prescription, and the percentage of drugs prescribed from the DOEN at Pasar Merah Medan Public Health Center was quite good. This study concludes that the use of drugs in Pasar Merah Medan Public Health Center has not met the indicator of drug use.

Keywords: Evaluation; Use; Medication; Public Health Center

\section{INTRODUCTION}

Public Health Center as referred to in the Regulation of the Minister of Health No. 75 of 2014 is a health service facility that organizes public health efforts and first-level individual health efforts, by prioritizing promotive and preventive efforts, to achieve the highest public health degree in its working area.

To carry out the activities of the Public Health Center, several standards are needed, including the standard of pharmaceutical services at the Public Health Center. The essence of the existence of pharmaceutical service standards at the Public Health Center is a measuring tool used by pharmaceutical personnel in services at the Public Health Center. (Minister of health regulation No.74 of 2016).

Functionally, the implementation of pharmaceutical service standards at the Public Health Center is carried out by the Head of the Pharmacy Division at the Public Health Center who has and is responsible for ensuring the implementation of the management of pharmaceutical preparations, and medical consumables as well as good clinical pharmacy services.

One of the standards that must be managed properly and correctly in pharmaceutical services is the use of drugs which must refer to indicators of drug use. Details of indicators of drug use include (WHO, 2003): a) Average number of drugs per prescription, b) Percentage of generic drugs prescribed, c) Percentage of antibiotics prescribed, d) Percentage of prescribed injections, and e) Percentage of drugs prescribed from DOEN.

\section{RESEARCH METHODOLOGY}

This study is an observational study, the data were taken retrospectively with a cross sectional research design. The data obtained are compared with WHO indicators (2012), and the target of the Ministry of Health of the Republic of Indonesia (2016).

\subsection{Population}

The population in this study were all prescriptions for outpatients from January to April 2018 at Pasar Merah Public Health Center in Medan which had prescription completeness requirements

\subsection{Sample}




\section{Journal of Pharmaceutical and Health Research}
Vol 2, No 2, Juni 2021, pp. 34-39
ISSN 2721-0715 (media online)
DOI 10.47065/jharma.v2i2.858

The sampling technique in this study is a saturated sample technique. Saturated sampling technique is sampling if all the population is a sample (Sugiyono, 2014). In this study, the sample was all prescriptions for outpatients from January to April 2018 at the Pasar Merah Public Health Center in Medan which had prescription completeness requirements.

\subsection{Tools}

WHO prescribing indicators (1993), consist of the average drug per patient, the percentage of generic prescriptions, the percentage of antibiotic prescriptions, the percentage of injection prescriptions, and the percentage of prescriptions from DOEN (National Essential Medicines List) that are still valid.

\subsection{Materials}

The ingredients used are all prescriptions for outpatients from January to April 2018 at the Red Market Public Health Center in Medan which have prescription completeness requirements

\subsection{Data Processing}

The data obtained were processed and presented in the form of a percentage table based on indicators of drug use.

\subsection{Data Analysis}

Data analysis is a descriptive approach research, carried out when the data is in progress, and after completing data collection within a certain period.

\subsection{Theoritical Review}

a. Pharmaceutical Service Standards At Public Health Center

Activities included in the standard of Pharmaceutical Services at the Public Health Center include:

1. Management of Pharmaceutical Preparations and Medical Consumables; and

2. Clinical pharmacy services

\section{b. Clinical Pharmacy Services}

Clinical pharmacy services are part of pharmaceutical services that are directly and responsibly to patients related to drugs and medical consumables with the aim of achieving definite results to improve the quality of life of patients.

Clinical pharmacy services aim to:

1. Improving the quality and expanding the scope of pharmaceutical services at the Public Health Center.

2. Providing pharmaceutical services that can ensure the effectiveness, safety and efficiency of drugs and medical consumables.

3. Increasing cooperation with other health professions and improve patient compliance related to pharmaceutical services.

4. Implementing drug policies at the Public Health Center in order to increase rational drug use.

Clinical pharmacy services include assessment and prescription services, drug information services (PIO), counseling, patient visits (specially for inpatients), monitoring drug side effects (MESO), and monitoring drug therapy (PTO), as well as evaluating drug use.

\section{c. Evaluation of Drug Use}

Evaluation of drug use is an activity to determine the use of drugs regularly and continuously to ensure that the drugs used are as indicated, effective, safe and affordable (rational).

Purpose of evaluating drug use:

1. Getting a pattern of drug use in certain cases.

2. Getting an overview of the use of certain drugs.

Every clinical pharmacy service must be carried out according to standard operating procedures. Standard Operating Procedures (SOPs) are set by the Head of the Public Health Center. The SOP is placed in a place that is easy to see. Indicators of drug use, among others (WHO, 2003) include:

1. Average number of drugs per prescription

2. The goal is to measure polypharmacy. Usually a combination of drugs is counted as a drug, the calculation is done by dividing the total number of drug products prescribed by the number of prescriptions surveyed.

3. Percentage of generic drugs prescribed

4. The goal is to measure the prescribing of generic drugs

5. Percentage of antibiotics prescribed

6. Used to measure the overuse of antibiotics.

7. Percentage of injections prescribed

8. The goal is to measure the use of excessive injection.

9. Percentage of drugs prescribed from DOEN (List of National Essential Medicines)

10. The aim is to measure the compliance of prescriptions with national drug policies Rational drug use according to WHO (1987), rational drug use if the criteria are met: 


\section{Journal of Pharmaceutical and Health Research}

\section{Vol 2, No 2, Juni 2021, pp. 34-39 \\ ISSN 2721-0715 (media online) \\ DOI 10.47065/jharma.v2i2.858}

1. According to the indication of the disease

2. Available at any time at an affordable price

3. Given with the right dose

Therefore, rational use of drugs is necessary because irrational use of drugs can cause:

1. Unsafe treatment.

2. Recurrence of disease.

3. The period of pain is prolonged.

4. Harmful, causing patient concern

5. Spending a lot of costs

\section{d. Rational Use of Medicine}

The use of drugs is said to be rational if the patient uses the drug according to his clinical needs, in the appropriate dose, in an adequate period of time and at a cost that is affordable by the community. The rationale for rational use of drugs is to increase the effectiveness and efficiency of drug spending, which is one of the cost effective medical interventions. In addition, to facilitate public access to drugs at affordable prices, prevent the impact of inappropriate drug use that endangers patients and increase patient confidence in the quality of health services.

Irrational use of drugs can result in a decrease in the quality of therapy that can increase morbidity and mortality rates, wasted resources that can reduce drug availability and increase treatment costs, the risk of unwanted effects triggering unwanted reactions and bacterial resistance, and psychosocial impacts that result in patient dependence on unnecessary drugs.

Assessment of rational drug use applies three main indicators, namely prescribing, patient care and health facilities. 3 This indicator can be used quickly to assess rational drug use in service units, compare between units, or assess changes after intervention. This indicator has been tested in 12 developing countries and has proven to be used for monitoring purposes.

\section{RESULTS AND DISCUSSION}

Quick et. al. (2012) stated that the drug management cycle includes four basic functions, namely selection, planning and procurement, distribution, and use which require planning and administration support. organizational management , information management and the development of human resources in it.

Then if it is made in the form of a drug management cycle, it must be supported by management support factors which include organization, administration, finance, Management Information Systems (MIS) and human resources (Satibi, 2015).

The results of research on the use of drugs at the Pasar Merah Health Center in Medan for the period January April 2018 are as follows:

\subsection{Average drug per prescription}

The results of the study to measure polypharmacy. The calculation is done by dividing the number of prescription drug products by the number of prescriptions surveyed. The data were taken retrospectively in the drug room at Pasar Merah Public Health Center in Medan.

Table 1. Average drug per prescription

\begin{tabular}{lcc}
\hline \multicolumn{1}{c}{ Information } & Value & Standard \\
\hline Number of patients & 3640 & \\
Number of drugs prescribed & 11705 & $1,6-1,8$ \\
Average drug prescribed for each patient & 3,4 & \\
\hline \multicolumn{2}{c}{ Data source: processed secondary data }
\end{tabular}

The results of this study indicate that polypharmacy in drug prescribing at Pasar Merah Medan Public Health Center is still high, not according to the specified standards. The factor that causes polypharmacy is the doctor's focus in providing therapy for the symptoms that arise, not the diagnosis of the disease, in addition, the results of the study show that most patients want the symptoms of the disease to disappear quickly, knowledge, and habits of doctors.(Bhartiy et al., 2008; Kardela et al., 2014). In addition, physician prescribing patterns can also be influenced by excessive commercial advertising from the pharmaceutical industry, advice from professional colleagues, academic literature and government regulations (Soumerai et al. 2005).

The impact of polypharmacy is the increase in costs that will be used in drug procurement, then the patient will have a tendency to choose a doctor who will prescribe many drugs with the belief that the doctor is more aware of the therapy for his disease (Basrahil, et al 2010). Patients will have a tendency to believe that there is a cure for all diseases so they will demand different drugs for the various symptoms they complain of (Bhartiy, et al. 2008).

The results of this study (3.4) are still below the results of research by Widya Kardela et al with the title Comparison of Rational Drug Use Based on WHO Indicators in Sub-district Public Health Centers between Depok City 
Journal of Pharmaceutical and Health Research

Vol 2, No 2, Juni 2021, pp. 34-39

ISSN 2721-0715 (media online)

DOI 10.47065/jharma.v2i2.858

and South Jakarta in 2011 which stated that the highest average number of drugs per prescription in non-treatment Public Health Centers South Jakarta (4.09) and the lowest is in Depok non-maintenance Public Health Centers $(3,85)$.

\subsection{Percentage of Prescribing Generic Drugs}

The results of the study to determine the tendency of prescribing generic drugs were obtained as follows

Tabel 2. Percentage of Prescribing Generic Drugs

\begin{tabular}{lll}
\hline \multicolumn{1}{c}{ Information } & Value & Standard \\
\hline Number of drugs prescribed & 11705 & \\
Number of generic drugs & 10425 & $100 \%$ \\
Percentage of Prescribing Generic & $93,64 \%$ & \\
Drugs & \\
\hline \multicolumn{2}{c}{ Data source: processed secondary data }
\end{tabular}

From the results of this study, it is known that there is a tendency to prescribe generic drugs at Pasar Merah Public Health Center in Medan with the assumption that it is still not good and it can be seen that the percentage of prescribing generic drugs with a value $(93.64 \%)$ is below the standard value. $(100 \%)$.

The results of this study are still below the results of the research by Widya Kardela et al., 2014 which stated that the largest percentage of generic drug prescriptions was Public Health Center in Depok City (99.15\%) while the lowest percentage was at Public Health Center in South Jakarta (96,64\%).

Public Health Centers as primary health care facilities are required by the Indonesian Ministry of Health to use generic drugs (Regulation of the Minister of Health of the Republic of Indonesia No. HK 02.02/Menkes/068/I/2010). However, the results of this study indicate that Pasar Merah Public Health Center Medan does not $100 \%$ prescribe drugs with generic names. Although it has not met the target set by the Indonesian Ministry of Health, the percentage of generic drug prescriptions at Pasar Merah Public Health Center in Medan is better than the results of previous studies in Indonesia, namely 59\% (Hogerzeil, et al., 1993)

\subsection{Percentage of Antibiotic Prescription}

The results of this study are used to determine the excessive use of antibiotics.

Table 3. Percentage of prescribing antibiotic

\begin{tabular}{lcc}
\hline \multicolumn{1}{c}{ Information } & Value & Standard \\
\hline Number of patients & 3640 & \\
Number of patients prescribed antibiotics & 1726 & $\leq 22,70 \%$ \\
$\%$ prescribing antibiotics & $49,02 \%$ & \\
\hline
\end{tabular}

Data source: processed secondary data

The results showed that the use of antibiotics at Pasar Merah Public Health Center in Medan was quite high, this situation could be seen from the percentage of antibiotic prescriptions with a value (49.02\%) above the standard value $(22.70 \%)$. The data is no better than what happened in Indonesia in 1993, namely 43\% (Hogerzeil, et al, 1993).

Excessive prescribing of antibiotics may be due to overestimation of the severity of the disease and the knowledge of doctors and patients so that symptoms of the disease disappear quickly (Bhartiy, et al, 2008)).

The most worrying consequence of the excessive use of antibiotics will be antibiotic resistance. Anti-biotic resistance can result in adverse impacts both economically (increased treatment costs) and clinically (increased disease severity). (Hogerzeil, et al, 2006 and WHO 1993). From the concerns and losses that will be caused, it is hoped that there will be a decrease in antibiotic prescribing in health care facilities through the issuance of local regional leadership policies regarding rewards and punishments for prescribing antibiotics.

\subsection{Percentage of Prescription Injection}

The results of the study aim to determine the use of excessive injections

Table 4. Percentage of injection prescriptions

\begin{tabular}{lcc}
\hline \multicolumn{1}{c}{ Information } & Value & Standard \\
\hline Number of patients & 3640 & \\
Number of patients prescribed injection & 76 & $0 \%$ \\
$\%$ injection prescribing & $2,12 \%$ & \\
\hline \multicolumn{2}{c}{ Data source: processed secondary data }
\end{tabular}

Although the results of the study gave a result of $2.12 \%$ so that it did not meet the percentage indicator of injection prescription at the Pasar Merah Public Health Center in Medan, this data showed better results than the results of previous studies in Indonesia, namely 10 - 80\% (Hogerzeil, et al, 1993). The high prescription for injections in 1993 was probably due to the belief in the community and doctors that injection preparations were more effective than other 


\section{Journal of Pharmaceutical and Health Research}

Vol 2, No 2, Juni 2021, pp. 34-39

ISSN 2721-0715 (media online)

DOI 10.47065/jharma.v2i2.858

preparations (Saleh \& Ibrahim, 2006). However, injection preparations have disadvantages, namely they are uncomfortable, more expensive, less safe, and require expertise in its use (Bashrahil, 2010).

To reduce the prescribing result until it is achieved and in accordance with the standard, the government is slowly intervening. The factors that influence the decrease in injection prescription are:

a. Government intervention: The government plays a major role in suppressing the high rate of injection prescriptions through the setting of therapeutic standards, regulation of drug procurement and increasing knowledge of health workers. (Arustiyono, 1999).

b. Increasing knowledge of doctors and Indonesian society. Public knowledge is no longer limited that going to a doctor must be injected if you want to recover.

The development of pharmacy in Indonesia has led to an increase in the choice of circulating drug preparations. Thus, the circulating drug preparations are no longer limited to injection preparations. Availability of drugs affects drug prescribing (Kartika, et al, 2011)

\subsection{Percentage of Drug Prescribing of DOEN}

The results of the study aim to determine the suitability of prescribing with national drug policies

Table 5. Percentage of Drug Prescribing of DOEN

\begin{tabular}{lcc}
\hline \multicolumn{1}{c}{ Information } & Value & Standard \\
\hline Number of drugs prescribed & 11705 & \\
Number of drugs prescribed according to & 11705 & \multirow{2}{*}{$100 \%$} \\
DOEN & $100 \%$ & \\
$\%$ drugs prescription of DOEN & & \\
\hline
\end{tabular}

Data source: processed secondary data

From the results of the study, it is known that the drugs prescribing of DOEN at Pasar Merah Public Health Center in Medan is quite good, this situation can be seen from the percentage of drug prescribing of DOEN with a value (100\%) equal to the standard value. (100\%). When compared with the 2014 study by Widya Kardela et al., the overall percentage of drug prescribing from DOEN ranged from $85.67 \%$ to $90.47 \%$.

The Ministry of Health of the Republic of Indonesia sets a standard that all drugs in Public Health Centers are drugs of DOEN. Factors that can affect the pattern of prescribing drugs from DOEN are the knowledge and habits of doctors, as well as the availability of drugs from DOEN at public health centers (The Ministry of Health of the Republic of Indonesia, 2008)). The implementation of the DOEN is intended to improve the accuracy, safety, rational use and management of drugs while at the same time increasing the effectiveness and efficiency of the available costs as one of the steps to expand, equalize and improve the quality of health services to the community (The Ministry of Health of the Republic of Indonesia, 2006.) The factors that influence the lack of utilization of essential drugs are insufficient prescription of essential drugs, incomplete availability, government commitment that is less in favor of services but on local revenue sources and intensive promotion of non-essential drugs (The Ministry of Health of the Republic of Indonesia, 2006.)

\section{CONCLUSION}

The results of the study can be concluded that the use of drugs at the Pasar Merah Public Health Center in Medan has not met the indicators of drug use and can be categorized as having not implemented rational drug use.

\section{REFERENCES}

Anief, M. 2001. Manajemen Farmasi. Yogyakarta: Gadjah Mada Press

Anonim. 2002. Pedoman Perencanaan dan Pengelolaan Obat. Jakarta: Departemen Kesehatan Republik Indonesia

Anonim. 2009. Peraturan Pemerintah No. 51 Tahun 2009 tentang Pekerjaan Kefarmasian

Ansel, C. Howard. 1985. Pengantar Bentuk Sediaan Farmasi, Edisi Keempat, Terjemahan : Farida Ibrahim. Jakarta: Universitas Indonesia Press

Arustiyono. Promoting Rational Use of Drugs at The Community Health Centers in Indonesia. Department of International Health School of Public Health. Boston University, 1999.

Bashrahil, K. A., Indicators of Rational Drug Use and Health Service in Hadramout, Yemen. Eastern Mediteranean Health Journal Vol.16 No.2, 2010, p 151-155.

Bhartiy, S. S., Shinde, M., Nandheswar, S., \&Tiwari, S.C. Pattern of prescribing practices in the Madhya Pradesh, India. Kathmandu University Medical Journal , 6 (1), 2008, p 55-59.

Depkes RI. 2008. Keputusan Menteri Kesehatan Republik Indonesia Nomor 791/Menkes/ SK/ VIII/2008 Tentang Daftar Obat Esensial Nasional 2008. Jakarta: Depkes RI.

Depkes RI. 2010. Peraturan Menteri Kesehatan Republik Indonesia Nomor HK.02.02/MENKES/068 /I/2010 tentang Kewajiban Menggunakan Obat Generik Di Fasilitas Pelayanan Kesehatan Pemerintah.Jakarta: Depkes RI.

Direktorat Bina Farmasi Komunitas dan Klinik. Direktorat Jendral Bina Kefarmasian dan Alat Kesehatan. Pedoman Pelayanan Kefarmasian di Puskesmas. Jakarta: Departemen Kesehatan RI, 2006. 


\section{Journal of Pharmaceutical and Health Research}

Vol 2, No 2, Juni 2021, pp. 34-39

ISSN 2721-0715 (media online)

DOI 10.47065/jharma.v2i2.858

Hogerzeil, H. V., Bimo, Ross-Degnan, D., Laing, R. O., Ofori-Adjei, D., Santoso, Kamaruzan, Saleh., Mohamed Izham Mohamed Ibrahim. How Rational Are Drug Used In Malaysian Primary Health Care

Sector. Malaysian Journal of Pharmaceutical Sciences, Vol.4, No.1, 2006. hal 1-12.

Hogerzeil, H.V., Bimo, Ross-Degnan, D., Laing, R.O., Ofori-Adjei, D., Santoso, B., et.al.1993 Desember 4. Field Test for Rational Drugs Use in Twelve Developing Countries. The Lancet, pp. 1408- 1410.

Kardela W., Retnosari A., dan Sudibyo S Perbandingan Penggunaan Obat Rasional Berdasarkan Indikator WHO di Puskesmas Kecamatan antara Kota Depok dan Jakarta Selatan. Indonesia J. Kefarmasian 2014.

Kartika Citra Dewi Permatasari. Evaluasi Rasionalitas Penggunaan Obat Ditinjau Dari Indikator Peresepan Menurut WHO Di Seluruh Puskesmas Kecamatan Kota Depok. Skripsi Program Studi Farmasi FMIPA-UI, Depok, 2011.

Kementerian Kesehatan Republik Indonesia. 2014. Peraturan Menteri Kesehatan Republik Indonesia Nomor 75 tahun 2014 tentang Puskesmas. Jakarta: Depkes R.I

Kementerian Kesehatan Republik Indonesia. 2016. Peraturan Menteri Kesehatan Republik Indonesia Nomor 74 tahun 2016 tentang Standar Pelayanan Kefarmasian di Puskesmas. Jakarta: Depkes RI.

Notoatmodjo, S. 2012. Metodologi Penelitian Kesehatan. Rineka Cipta : Jakarta

Quick, J.D., 2012. MDS-3: Managing Access to Medicines and Health Technologies | Management Sciences for Health. Management Science for Health, USA.

Satibi. Manajemen Obat Di Rumah Sakit. Yogyakarta: Gadjah Mada University Press; 2014.

World Health Organization.. How to Investigate Drug Use in Health Facilities. Geneva: World Health Organization, 1993.

World Health Organization., Promoting rational use of medicines : Core Components. Dalam World Health Organization, 2012 